\title{
Intrinsic and Extrinsic Biomarkers for the Assessment of Risks from Environmental UV Radiation
}

\author{
Petra Rettberg, and Gerda Horneck
}

\begin{abstract}
In the last decades the knowledge of the effects of UV radiation on human health, especially in skin cancerogenesis, but also in immunsuppression, photoaging, eye damages, has enlarged strongly. The increasing solar UV radiation and changes in life style strengthen the necessity to identify and quantitate intrinsic biomarkers which are indicative for the individual UV susceptibility and the accumulated individual UV burden. For the risk assessment of potentially deleterious UV effects extrinsic biomarkers have to be developed and tested as personal biological UV dosimeters. One example for such a well characterized biological UV dosimeter is the DLRbiofilm which consists of spores of the bacterium Bacillus subtilis as UV sensitive target. J Epidemiol, 1999 ; 9 : S78-S83.
\end{abstract}

biomarker, biological UV dosimetry, DLR-biofilm

\section{BIOLOGICAL UV EFFECTS}

The increased exposure of the human population to UV radiation, as a result of depletion of stratospheric ozone leading to an increase of ground-level UVB, but also as a result of a change in life style and leasure activities, has led to concern about potential deleterious health effects.

In the skin a well-known UV-induced acute effect is the formation of erythema. Chronic changes include skin cancer (both melanoma and non-melanocytic), benign abnormalities of melanocytes, and a range of other chronic injuries to keratinocytes, blood vessels and fibrous tissue (photoaging). On the eye UV induces acute, but reversible effects like photokeratitis and photoconjunctivitis as well as chronic effects like pterygium, squameous cell cancer of the conjunctiva and cataracts. The function of the immune system can be modified by UV. The immune response appears to become suppressed. This may enhance the risk of infection and decrease the effectiveness of vaccines in humans ${ }^{1}$.

Up to now the observed interindividual differences in the susceptibility of humans belonging to the same population to cancer in general or to UV-induced skin cancer in particular is not completely understood ${ }^{2,3)}$.

Complex phenomena like cancer induction or skin aging are visible biological endpoints of a complicated chain of events between the first step, the physical absorption of UV by cellular target molecules, the following photochemical and photobiological reactions and the final manifestation in the organism, which may occur even years later. At the cellular level different defense mechanisms against the deleterious effects of UV have been established. The most critical target inside the cell is the DNA. Every organism, fom bacteria to humans, has developed several DNA repair pathways which are able to restore the original information coded by the DNA. Many of these mechnisms are able to complement and/or replace each other ${ }^{4-7}$.

\section{INTRINSIC BIOMARKERS}

To understand the reason for the individual UV susceptibility and to asses the risks resulting from ambient UV exposure and from artificial UV sources it is necessary to investigate the molecular and cellular damage-processing reactions and the resulting changes in signal transduction in more detail. It should be possible to define biochemical parameters which can be used as intrinsic biomarkers for the individual UV burden and for the risk assessment.

For monitoring of short-term UV effects the identification and quantification of DNA photoproducts can be used. Some photoproducts like pyrimidindimers are formed by direct ener-

DLR, Institute of Aerospace Medicine, Radiation Biology, D - 51170 Köln, Germany.

Address for correspondence : DLR, Institute of Aerospace Medicine, Radiation Biology, D - 51170 Köln, Germany. 
gy absorption of the DNA ${ }^{899}$.

Other photoproducts are the result of the indirect UV effect where different cellular UV targets, the socalled photosensitizers, are excited by UV radiation and react with cellular components thereby creating reactive oxygen species (ROS). The ROS themselves can react with DNA to give typical oxidative DNA damages, e.g. 8-hydroxyguanin, which are found in elevated levels in precancerous and cancerous tissues ${ }^{10)}$. Macromolecular carbonyls in the human stratum corneum which can be measured non-invasively, have been proposed as a biomarker for environmental oxidant exposure including UV ${ }^{11)}$.

The cellular UV-damage processing can result in typical 'UV signature mutations' because some of the repair mechanisms are error-prone. These mutations can also be used as intrinsic biomarkers for previous longer-lasting UV exposures, especially, if these mutations occur in important genes like tumor suppressor genes or protooncogenes, for instance in the tumor suppressor gene $\mathrm{p} 53^{12,13)}$.

Other examples of bioassays for the determination of individual cancer susceptibility are the measurement of the individual DNA repair capacity or the of kinetics of enzymatic DNA repair reactions ${ }^{14,15)}$.

$\mathrm{UV}$-induced gene expression, for instance of c-fos or c-jun ${ }^{16)}$ or of genes for the antioxidative defence mechanisms can also serve as biomarker. Other gene products which are important for skin tumor promotion and progression like angiogenesis factors or matrix-metalloproteinases have to be examined as possible candidates for intrinsic biomarkers ${ }^{17}$.

Due to the complexity of all these reactions the UV doseresponse relationship is very often unknown. Biological UV effects are always strongly wavelength-dependent. Many effects increase with decreasing $U V(A+B)$ wavelengths. Quite different examples for biological action spectra describing the relative wavelength efficiency are given in Fig. $1{ }^{18)}$. The experiments which are necessary to determine the doseresponse functions and the wavelength-dependencies are extensive and long-lasting. They require a careful experimental design with special emphasis on accurate UV dosimetry at the position of the sample during the irradiations.

Therefore, it is desirable to develop in parallel to the identification and characterization of intrinsic biomarkers extrinsic biomarkers which can be correlated to the intrinsic ones and serve as a tool for the assessment of the individual UV burden.

\section{EXTRINSIC BIOMARKERS FOR BIOLOGICAL UV DOSIMETRY}

Different biomolecules and simple biological systems have been proposed and tested as extrinsic biomarkers for biological UV dosimetry (see Tab. 1 , from ${ }^{19}$, and the literature cited there). They weight the UV radiation according to its biological effectiveness per se. However, to be applicable as a reliable UV dosimeter they have to fulfill several criteria which are summarized in Tab. 2. Some of these criteria are specific for wavelength- and time-integrating biological UV dosimeters, most of the others also have to be fulfilled by any other radiometer.

\section{THE BIOLOGICAL UV DOSIMETER 'DLR-BIOFILM'}

One of these systems, the 'DLR-biofilm', has been developed

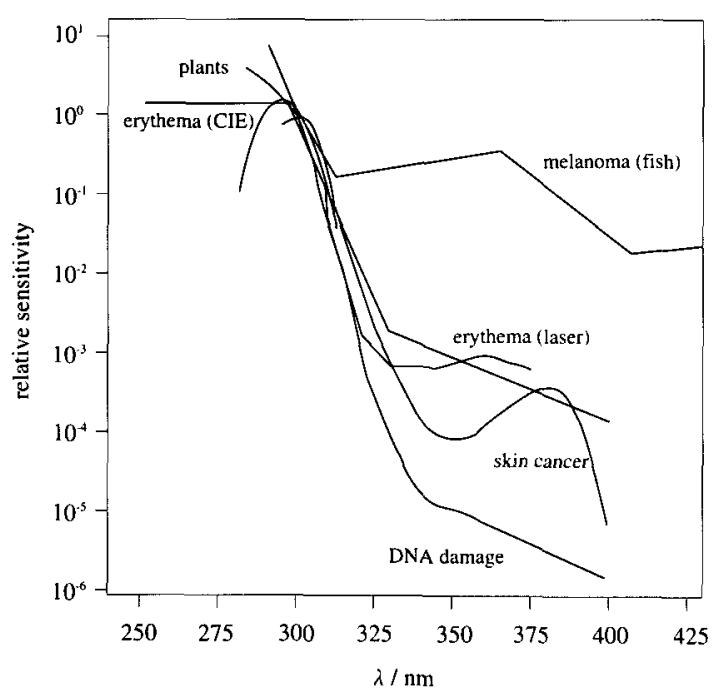

Figure 1. Examples for different biological action spectra (normalized at $300 \mathrm{~nm}$ ) (modified from a summary in ${ }^{18}$ ). 
Table 1. Examples for extrinsic biomarkers as biological UV dosimeters*.

\begin{tabular}{|c|c|c|c|}
\hline biological detector & biological endpoint & dosage unit & application \\
\hline uracil & dimer formation & dose to reduce $\mathrm{A}$ by $\mathrm{e}^{-1}$ & long-term monitoring \\
\hline vitamin $\mathrm{D}$ & isomerisation to pre-D3 & $\begin{array}{l}\% \text { conversion of } \\
7 \mathrm{DHC}\end{array}$ & $\begin{array}{l}\text { seasonal and latitudinal } \\
\text { exposures }\end{array}$ \\
\hline $\begin{array}{l}\text { DNA } \\
\text { bacteriophage } \mathrm{T} 7\end{array}$ & $\begin{array}{l}\text { inactivation, dimer formation, } \\
\text { inactivation of plaque } \\
\text { formers }\end{array}$ & $\begin{array}{l}\text { effective dose, quivalent to } 254 \mathrm{~nm}\left(\mathrm{~J} / \mathrm{m}^{2}\right) \\
\text { average number of hits in the population } \\
(1 \ln (\mathrm{N} / \mathrm{Nol})\end{array}$ & $\begin{array}{l}\text { clear tropical marine water } \\
\text { long-term/continuous monitoring } \\
\text { at different sites; measurements } \\
\text { in lakes, rivers, ocean }\end{array}$ \\
\hline $\begin{array}{l}\text { bacterial cells } \\
\text { E. coli sp. }\end{array}$ & $\begin{array}{l}\text { inactivation, mutagenesis, } \\
\text { repair, interactions }\end{array}$ & $\begin{array}{l}\text { inactivation rate constant, dose equivalent to } \\
\text { that at } 254 \mathrm{~nm}, \% \text { enhancement of survival by } \\
\text { removal of UVB }\end{array}$ & $\begin{array}{l}\text { diurnal profiles, daily totals, } \\
\text { vertical dose distribution in } \\
\text { natural water }\end{array}$ \\
\hline $\begin{array}{l}\text { bacterial spores } \\
\text { B. subtilis sp. }\end{array}$ & inactivation; mutagenesis & $\begin{array}{l}\text { inactivation rate constant; mutation doubling } \\
\text { constant, dose equivalent to that at } 254 \mathrm{~nm}\end{array}$ & $\begin{array}{l}\text { diurnal profiles, daily totals, long } \\
\text { term monitoring }\end{array}$ \\
\hline $\begin{array}{l}\text { DLR-biofilm } \\
\text { B. subtilis sp. }\end{array}$ & loss of biological activity & Heff equivalent to $254 \mathrm{~nm}\left(\mathrm{~J} / \mathrm{m}^{2}\right)$ eff & $\begin{array}{l}\text { long term monitoring, personal } \\
\text { dosimetry, trend estimation }\end{array}$ \\
\hline $\begin{array}{l}\text { bacterial cells } \\
\text { E. coli sp. }\end{array}$ & $\begin{array}{l}\text { inactivation, mutagenesis, } \\
\text { repair, interactions }\end{array}$ & $\begin{array}{l}\text { inactivation rate constant, dose equivalent to } \\
\text { that at } 254 \mathrm{~nm}, \% \text { enhancement of survival by } \\
\text { removal of UVB }\end{array}$ & $\begin{array}{l}\text { diurnal profiles, daily totals, } \\
\text { vertical dose distribution in } \\
\text { natural water }\end{array}$ \\
\hline $\begin{array}{l}\text { bacterial spores } \\
\text { B. subtilis sp. }\end{array}$ & inactivation; mutagenesis & $\begin{array}{l}\text { inactivation rate constant; mutation doubling } \\
\text { constant, dose equivalent to that at } 254 \mathrm{~nm}\end{array}$ & $\begin{array}{l}\text { diurnal profiles, daily totals, long } \\
\text { term monitoring }\end{array}$ \\
\hline $\begin{array}{l}\text { DLR-biofilm } \\
\text { B. subtilis } s p \text {. }\end{array}$ & loss of biological activity & Heff equivalent to $254 \mathrm{~nm}\left(\mathrm{~J} / \mathrm{m}^{2}\right)_{\text {eff }}$ & $\begin{array}{l}\text { long term monitoring, personal } \\
\text { dosimetry, trend estimation }\end{array}$ \\
\hline
\end{tabular}

*from (19)

and tested as field UV dosimeter, for instance in remote areas like Antarctica or in space, and as personal UV dosimeter ${ }^{20-22)}$.

The biofilm is a wavelength- and time-integrating biological UV dosimeter which weights the UV radiation according to its DNA-damaging potential. It consists of dried spores of the bacterium $B$. subtilis immobilized on the surface of a plastic sheet. After UV exposure each biofilm is calibrated in the laboratory with a standard UVC lamp on previously unexposed calibration areas. The following incubation in nutrient medium results in bacterial growth from undamaged or only slightly damaged spores. After staining of the biomass formed thereby inside the biofilm the evaluation is done by image analysis. As result the biologically effective dose for each measurement area is obtained as equivalent dose of an irradiation with UVC of $254 \mathrm{~nm}$ giving the same biological effect. Exposure boxes for different biofilm formates were constructed which allow the exposure of several measurement areas on each biofilm to natural or artificial UV sources. The design depends on the individual measurement purpose, e.g. long-term or short-term stationary measurements, automatic determination of diurnal UV profiles of one week per biofilm, or underwater measurements.

For the application as personal UV dosimeter additional requirements have to be fulfilled than those concerning the radiometric properties mentioned in Tab. 2. like (i) a large dynamic range due to significant individual variations in sun exposure, (ii) the avoidance of shadowing of the measurement areas by the dosimeter housing itself while the person is moving relative to the UV source, (iii) protection of the UV sensor against physical and chemical damages during use, (iv) lightprotected calibration areas and dark control areas, (v) comfortable wearing, (vi) easy handling. The DLR-biofilm exposure housings of personal UV dosimeters are made of plastics and contain the biofilm in a water-tight biofilmstack (Fig. 2). Polyamid gazes which serve as neutral density filters are integrated in the frame for the separation of individual measurement areas in addition to a foil used as cut-off filter for UVB.

These biofilm dosimeters are in use now to determine the individual UV exposure in different groups of the German population, like school children, indoor workers etc. Measurement periods of two weeks including three weekends were choosen in different seasons, thereby excluding holiday periods. One biofilm dosimeter is worn during the working days, another one during the weekends to obtain informations about the magnitude and distribution of UV exposure during normal work and during leasure activities. In addition, a protocol of outdoor periods should be written with the accuracy of half an hour. Stationary UV measurements with biofilms, but also with RB-meters and a spectroradiometer are performed in parallel. Fig. 3 shows exemplary the results for a group of school children in May/June 1997. In general the UV exposure in each group was very inhomogenious due to the strong dependence on behaviour, ranging from more than $400 \mathrm{Jeff} \mathrm{m}^{-2}$ to less than $10 \mathrm{Jeff} \mathrm{m}^{-2}$ for the sum of the three weekends. 
Table 2. Criteria for reliable biological UV dosimeters.

1 Indicative of a biological effect of possible risk or benefit by solar radiation

- the reaction must be UV specific (in UVB and UVA range)

- the reaction should be general

- the reaction must indicate a biologically significant process, e.g. in human health, ecosystem balance, agricultural and fishery productivity

2 Spectral response (UVB and UVA) in agreement with a specific photobiological process

- with respect to monochromatic radiation

- with respect to polychromatic radiation

These action spectra (mono-and polychromatic) must be described with the highest accuracy possible.

3 Quantification of the biological effectiveness of solar UV radiation in measurable units that can be

- compared with other measurements (e.g. calculated data from spectroradiometry, or other radiometers)

- converted into other units of photobiological/medical importance (e.g. MED)

The error budget shall be estimated.

4 Production of reproducible data

- the procedure must be standardized

- the biological sensitive system must be well defined, e.g. genetically well defined strains

- the operation of the dosimeter must be independent of environmental conditions (e.g. temperature, relative humidity, rain etc.)

- stability with time

The dosimeter should be positioned in a defined manner, depending on the purpose (e.g. horizontally, personal dosimetry).

5 Compliance with the general requirements for radiometers

- absolute responsivity to UVB, UVA and UVB+UVA (calibration)

- relative spectral response

- linearity of response (law of reciprocity)

- angular response

The feasibility of the biological dosimeter should be proven by intercomparison with biologically weighted spectroradiometry.

6 Robustness

- have a long shelf life

- be resistant against environmental extremes during pre-and post-exposure storage (e.g. heat, cold, humidity etc.)

7 Suitability for routine measurements

- easy handling

- safe to the environment

- automatic registration

- cost-effectiveness 


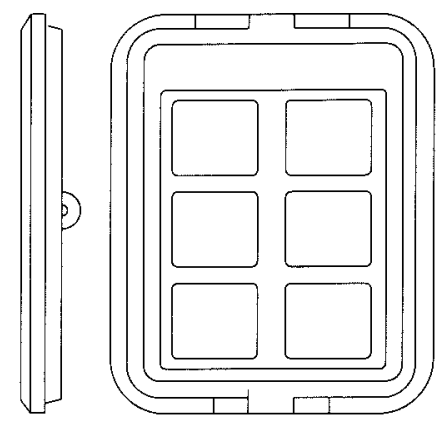

Figure 2. Plastic housing of the personal biofilm UV dosimeter.
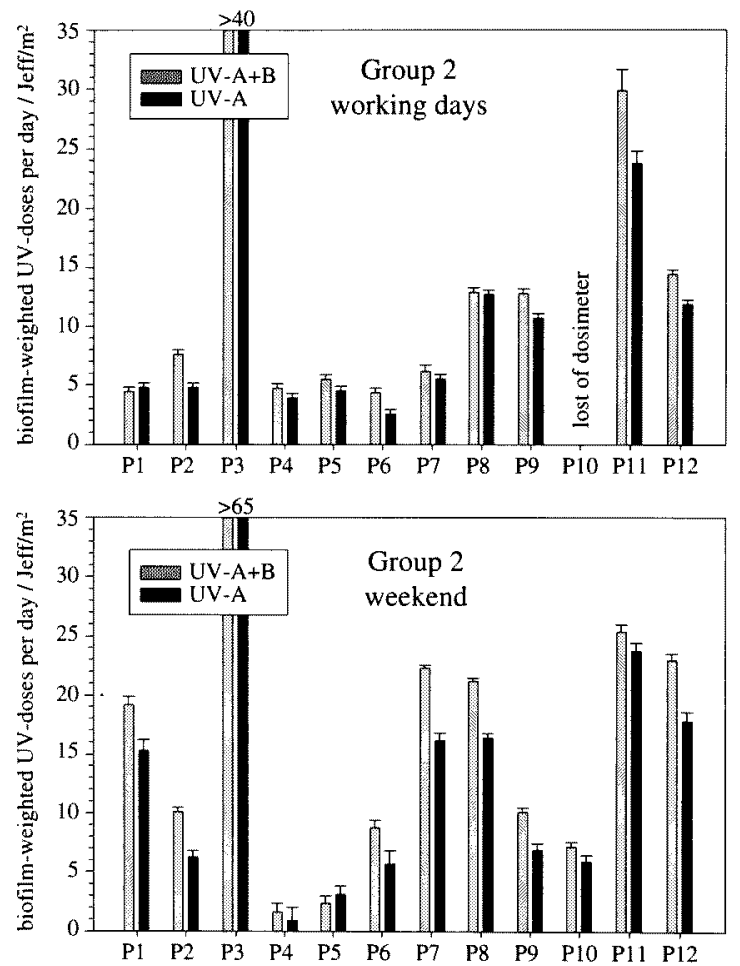

Figure 3. Biologically effective personal UV doses of a group of 12 school children in May/June 1997 in Germany.

\section{CONCLUSIONS}

Further experiments to identify and quantitate intrinsic biomarkers for UV exposure and for individual cancer susceptibility are necessary. The use of biological UV dosimeters, like the 'DLR-biofilm', can support the assessment of risk resulting from ambient solar UV, but also from artificial UV sources like sunbeds.

\section{ACKNOWLEDGEMENTS}

This work was partly supported by the EC, DG XII, ENV4CT-95-0044 and by BMBF, Germany, 07UVB54A. 


\section{REFERENCES}

1. WHO. Ultraviolet Radiation. Environmental Health Criteria 160, WHO, Genf, Suisse, 1994.

2. Lai $\mathrm{C}$, Shields $\mathrm{PG}$. The role of interindividual variation in human carcinogenesis. J Nutr 1999; 129 (2S Suppl): 552S - 555S.

3. Bridges BA. UV-induced mutations and skin cancer: how important is the link? Mutat Res 1998; 422 (1): 23 - 30.

4. Lehmann AR. Dual functions of DNA repair genes: molecular, cellular, and clinical implications. Bioessays 1998; 29 (2): 146 - 155.

5. Stecca C, Gerber GB. Adaptive response to DNA-damaging agents: a review of potential mechanisms. Biochem Pharmacol 1998; 55 (7): 941 - 951.

6. Taylor EM, Lehmann AR. Conservation of eukaryotic DNA repair mechanisms. Int J Radiat Biol 1998; 74 (3): $277-286$.

7. Yu Z, Chen J, Ford BN, Brackley ME, Glickmann BW. Human DNA repair systems: an overview. Environ Mol Mutagen 1999; 33 (1): 3 - 20.

8. Hacham H, Freeman SE, Gange RW, Maytum DJ, Sutherland JC, Sutherland BM. Do pyrimidine dimer yields correlate with erythema induction in human skin irradiated in situ with ultraviolet light $(275-365 \mathrm{~nm})$ ? Photochem Photobiol 1991; 53 (4): 559 - 563.

9. Ueda M, Matsunaga T, Bito T, Nikaido O, Ichihashi M. Higher cyclobutane pyrimidine dimer and (6-4) photoproduct yields in epidermis of normal humas with increased sensitivity to ultraviolet $B$ radiation. Photodermatol Photoimmunol Photomed 1996; 12 (1): 22 $-26$.

10. Olinsli R, Jaruga P, Zastawny TH. Oxidative DNA base modifications as factors in mutagenesis. Acta Biochim Pol 1998; 45 (2): 561 - 572.

11. Thiele JJ, Traber MG, Re R, Espuno N, Yan LJ, Cross CE, Packer L. Macromolecular carbonyls in human stratum corneum : a biomarker for environmental oxidant exposure ? FEBS Lett 1998; 422 (3): 403 - 406.

12. Brash DE, Zeigler A, Jonason AS, Simon JA, Kunala S, Leffell DJ. Sunlight and sunburn in human skin cancer: p53, apoptosis, and tumor promotion. J Investig Dermatol Symp Proc 1996; 1 (2): 136 - 142.

13. Pfeifer GP, Denissenko MF. Formation and Repair of DNA lesions in the p53 gene: relation to cancer mutations? Environ Mol Mutagen 1998; 31 (3): 197 - 205.

14. Wei Q. Effect of aging on DNA repair and skin carcinogenesis: a minireview of population-based studies. J Investig Dermatol Symp Proc 1998; 3 (1): 19 - 22.

15. Rajewsky MF, Engelbergs J, Thomale J, Schweer T. Relevance of DNA repair to carcinogenesis and cancer therapy. Recent Results Cancer Res 1998; 154: 127 - 146.

16. Dosch J, Kaina, G. Induction of c-fos, c-jun, junB and junD mRNA and AP-1 by alkylating mutagens in cells deficient and profiecient for the DNA repair protein $\mathrm{O}^{6}$ methylguanine-DNA methyltransferase (MGMT) and its relationship to cell death, mutation induction and chromosomal instability. Oncogene 1996; 13 (9): 1927 - 1935.

17. Brenneisen P, Oh J, Wlaschek M, Wenk J, Briviba K, Hommel C, Herrmann S, Sies H, Scharffetter-Kochanek K. UVB-wavelength-dependece for the regulation of two major matrix-metalloproteinases and thei inhibitor TIMP1 in dermal human fibroblasts. Photochem Photobol 1996; 64: 649 - 657.

18. Horneck G. Quantification of the biological effectiveness of environmental UV radiation. Photochem Photobiol B 1995; $31: 43$ - 49.

19. Horneck G. Biological dosimetry of solar UV radiation. Trends Photochem Photobiol 1997; 4: 67 - 78.

20. Quintern LE, Horneck G, Eschweiler U, Bücher H. A biofilm used as ultraviolet-dosimeter. Photochem Photobiol 1992; 55 (3): 389 - 395.

21. Quintern LE, Puskeppeleit M, Rainer P, Weber S, El Naggar S, Eschweiler U, Horneck G. Continuous dosimetry of the biologically harmful UV-radiation in Antarctica with the biofilm technique. J Photochem Photobiol B 1994; 22: 59 - 66 .

22. Horneck G, Rettberg P, Rabbow E, Strauch W, Seckmeyer G, Facius R, Reitz G, Strauch K, Schott JU. Biological dosimetry of solar radiation for different simulated ozone column thicknesses. J Photochem Photobiol B 1996; 32: $189-196$. 